\title{
Polarising Development - Introducing Alternatives to Neoliberalism and the Crisis
}

\author{
Thomas Marois and Lucia Pradella
}

\section{Polarising the Debate on Alternatives}

Neoliberal economic policies, with their emphasis on market-led development and individual rationality, have been exposed as bankrupt not only by the global economic crisis but also by increasing social opposition and resistance. Social movements and critical scholars in Latin America, East Asia, Europe and the United States, alongside the Arab uprisings, have triggered renewed debate on possible different futures. While for some years any discussion of substantive alternatives has been marginalised, the global crisis since 2008 has opened up new spaces to debate, and indeed to radically rethink, the meaning of development. Debates on developmental change are no longer tethered to the pole of 'reform and reproduce': a new pole of 'critique and strategy beyond' neoliberal capitalism has emerged.

Despite being forcefully challenged, neoliberalism has proven remarkably resilient. In the first years since the crisis erupted, the bulk of the alternative literature pointed to continued growth in the BRICS (Brazil, Russia, India, China and South Africa) and in other big emerging market countries to affirm the necessary role for the state in sustaining capitalist development. New developmental economists have consequently reasserted themselves. Their proposals converged into a broader demand for global Keynesianism (Patomäki, 2012) - a demand that is proving to be less and less realistic in the face of a deepening global economic crisis.

Advocates of 'reform and reproduce' - be they new developmental or neo-Keynesian - share deep commitments to capitalism and the subordination of workers to the needs of accumulation. In contrast, this book represents a collaborative attempt by a group of Marxian-inspired scholars to explore real and potential alternatives to the exploitative reality of neoliberal capitalism. Despite varying approaches, contributors to this book understand that neoliberalism and the ongoing crisis are an expression of the fundamental contradictions of 


\section{reproduced by specific permission under license}

capitalism. They reflect on the alternatives that workers, women, peasants and oppressed peoples have defended and struggled to create. At the same time the book seeks to provide an analysis of capitalism, and its crisis, as a global phenomenon, and in doing so overcome academic divisions between development studies of the South and the study of neoliberalism in the North.

Importantly, a guiding theme helping to shape the book has been a refusal to accept nation-states as self-contained units of analysis: that is, the 'methodological nationalism' found in much of the developmental literature. Contributors instead seek to understand the case-specific dynamics of neoliberalism in ways that capture the global tendencies of capitalist accumulation as an integrated whole. In this approach contemporary development is not separated from existing labour and social movements, just as concrete alternatives depend on real social mobilisations. Capitalist development is taken as an inherently antagonistic and polarising process shaped by class struggle. Alternatives are assessed by the extent to which they enable the fulfilment of social aspirations for an equal and just existence free from exploitation and oppression. The contributors' critical analyses thus seek to reveal the contours of different and better possible forms of social development.

The book is structured as follows. Part I, Alternative Themes, develops a broad analysis of capitalist relations of production, social reproduction, climate change, crisis and alternatives. Part II, Alternative Cases, explores the specificities of capitalist development in Latin America, Asia, Africa, the Middle East, North America and Western Europe. The remainder of this Introduction is intended to orient the reader to the book's key concepts, with reference to specific contributors as relevant. It is organised around four sections. The first explores neoliberalism in historical and conceptual terms. The second considers the current crisis and the alternative opportunities it may or may not have opened up. The third questions the extent to which new developmentalist approaches offer substantive alternatives to neoliberalism. The final section then pulls together some of the vital theoretical and practical elements of what our contributors pose as alternatives. As a whole, the book intends to spur debate on the nature and varieties of neoliberalism, the social impacts of its crises, and the forms alternatives must take.

\section{Interpreting and Resisting Neoliberalism}

Neoliberalism is a historical phenomenon. In the early 1970s firms began to feel acutely the impact of falling profitability. Many managers and owners believed the mounting power of organised labour was responsible. Indeed, this emerging structural crisis of capitalism was amplified by increasing labour militancy and social opposition, and by the rising challenge of socialism and nationalism from the Global South - the greatest wave of decolonisation in world history (Arrighi, 2007: 136). The power of the United States reached its nadir with its defeat in Vietnam (1975), with the Iranian Revolution in the late 1970s, and with the 
reproduced by specific permission under license

spread of revolutionary struggles, notably in Latin America. It is against this backdrop that the rise of neoliberalism becomes understandable.

Neoliberalism's set of pro-market and anti-labour policies were first implemented by the brutal US-backed Pinochet dictatorship in Chile (1973). The monetarist economic principles of the infamous 'Chicago Boys' guided the process. At this time, however, many other governments in the South resisted initial demands by the Northern-dominated international financial institutions (IFIs), notably the World Bank and International Monetary Fund (IMF), to implement rapid 'shock therapy' structural adjustment programmes.

The 1979 to 1982 Volcker Shock changed matters dramatically. Paul Volcker, then head of the US Federal Reserve, allowed US interest rates to skyrocket from around 5 per cent to over 20 per cent, ostensibly to halt persistent inflation and to shock the US economy out of stagnation. This move sparked a global rise in interest rates and a wave of profound economic crises in Africa, Asia, Latin America and the Soviet bloc. Governments in these countries lost the ability to service their debts because of the dramatic falls in the prices received for and the quantity of their primary goods exported. This triggered the 1980s debt crisis, which opened an opportunity for governments North and South to press more systematically for neoliberal transformation.

Instead of mobilising workers and peasants against this new form of economic imperialism, governments in the South began to reorient their economies toward intensified export production in order to earn the foreign currency needed to repay their loans. With the fall of the Soviet Union, neoliberal shock therapy was also extended to Russia and other Eastern European countries. In the former Yugoslavia, Iraq and Afghanistan, Western governments mobilised their military power to facilitate the entrenchment of neoliberal policies at a terrible human cost.

Neoliberalism has entailed processes of contested socio-economic transformation. Amidst great popular resistance and economic instability, post-war state-led strategies of development gave way to market-oriented neoliberal ones, or the so-called 'Washington consensus'. The economist John Williamson identified ten policies characteristic of the consensus: fiscal discipline, reduction in public expenditure, tax reform, financial liberalisation, market-determined exchange rates, trade liberalisation, an open door to foreign direct investment, privatisation of public service and state-owned enterprises, deregulation, and secure property rights. These policies have led to higher unemployment, worsening social inequalities, widespread impoverishment, peasant land dispossessions, unsustainable urbanisation and increased worker exploitation.

Contributors to this book describe many of the specific developmental transformations in the Global South, and how neoliberal processes have led to an expansion of the global reserve army of workers and accelerated international migration. At the same time, financial and trade deregulation have enhanced the power of finance capital and multinational corporations, which they have used to pursue the outsourcing and offshoring of many industrial and service 


\section{reproduced by specific permission under license}

activities. This globalisation of production has brought with it intensified processes of ecological destruction.

Women and the poor are the most negatively impacted by the neoliberal privatisation of public services. As women increasingly enter into the workforce, the privatisation of public services magnifies their 'double burden'. Such transformations have been global, having negative impacts on workers in the South and, increasingly, in the North.

The neoliberal policies shaping these transformative processes are derived from neoclassical economic theory. Neoclassical theory obscures and naturalises the exploitative foundations of capitalism because it reduces labour to just another factor of production, not unlike other 'technical inputs' like land and capital. The social reproduction of workers is further assumed to be a private, genderless process restricted to the household, when it is in fact vital to overall capital accumulation processes. In not dissimilar ways, neoclassical economics tends to treat the environment as an externality. Further embedded in this kind of approach is a tendency towards methodological nationalism. Certain models presuppose that capital and labour do not move internationally and that international trade represents merely exchange of commodities between national units. It follows, in theory, that by promoting domestic specialisation according to a given country's comparative advantage, free trade would spontaneously stabilise participating 'national' economies at an equilibrium level, maintaining employment and growth in all of them.

With its emphasis on liberal, market-based notions of individual equality and freedom, neoclassical economics conceals underlying social polarisations and exploitative relationships characteristic of capitalism. In reality, neoliberal transformation favours the interests of the strongest capitals internationally (see Shaikh, 2005). Despite the proclaimed spontaneity of the market, moreover, neoliberalism does not lead to a retreat of the state. Rather, neoliberalism is marked by the class-based restructuring of the state apparatus in ways that have responded to the evolving needs of capital accumulation (for example, around new financial imperatives). What is more, as today's capitalism is dominated by Northern powerhouses like the United States and Western European countries, the extension of capitalist relations globally embodies these imperialist powers' aspirations to retain supremacy in the hierarchy of states.

Neoliberalism, in fact, has always occurred through and within states, never in the absence of states. Actually existing neoliberal transformations are mediated by the hierarchical position of a given state within the world market and by specific social struggles. Consequently, neoliberal transition in the United States is not the same as neoliberalism transition in India or Iraq, and each entails specific national, class, racial and gendered dimensions. Yet contributors to this book recognise that neoliberalism is a class-based political and economic project, defined by the attack of capital and neoliberal state authorities on the collective capacity of organised labour, the peasantry and popular classes to resist the subordination of all social, political, economic and ecological processes to 
reproduced by specific permission under license

accumulation imperatives. The subsequent consolidation of neoliberalism globally has thus been to the benefit of global capital, and has come at the expense of workers, women and the poor. Relations of imperialist domination, environmental exploitation, racial and gender oppression are constitutive dimensions of this class struggle.

Neoliberal consolidations nonetheless generate new social resistances. Many contributors to this book identify continuing processes involving the recomposition of working classes and the formation of important social movements. With the 1999 demonstrations in Seattle, these struggles assumed an inter-American character. Various indigenous groups, trade unionists, faith-based and women's organisations marched alongside environmentalists and farmers in a collective bid to shut down the World Trade Organization (WTO) talks (Burbach, Fox and Fuentes, 2013: 2). In the new millennium, the 'alter-globalisation' movement has attained a truly global scale. Yet the movement has not been without problems. Notably, the activists and organisations have failed to produce precise sets of collective demands or a coherent international political programme. Pre-existing antagonisms among workers and peoples across lines of national and social oppression were not overcome. The movement, as a result, failed to articulate collective resistance across national, regional and international levels (Prashad, 2013: 235). After the huge demonstrations against the war on Iraq (2003), it gradually faded away.

Still, resistances to neoliberalism grew thereafter, especially in the Global South. In some cases these made significant advances. For example, while the United States and other Western states were bogged down with military aggressions in the Middle East, US control over Latin America eased. Social mobilisations there enjoyed new spaces for action, which helped give rise to a variety of progressive governments less subservient to imperialist interests and the competitive imperatives of neoliberal development. In this book, Abelardo Mariña-Flores suggests that progressive income redistribution and the reinforcement of regional integration processes are among the most significant achievements. Susan Spronk and Sarah Miraglia highlight the progressive, albeit imperfect, gendered dimensions of the Bolivarian transformative movement in Venezuela.

Neoliberal transformations also create new socio-economic conditions that may undermine US and Western hegemony. As several authors attest, for example, the relocation of industrial production towards East Asia has generated new centres of accumulation. Consequently, Western imperial powers now face a major challenge with the rise of China and India. So too have other big emerging capitalisms, like Brazil, Russia, South Africa, Indonesia and the Gulf States, become ever more important centres of accumulation. This has lent support to arguments suggesting global hegemony has started to shift from the West to the East.

To be sure, these emerging capitalisms, China in particular, offer alternative sources of foreign direct investment, international aid, developmental loans and 


\section{reproduced by specific permission under license}

technological know-how to countries in Asia, Africa and Latin America. Leaders of the BRICS have, for example, called for a 'multipolar' reform of the financial system and of the IFIs, which includes the establishment of a new multilateral Development Bank, the 'BRICS Bank'. Yet the extent to which these changes offer an alternative at all has everything to do with the extent to which SouthSouth relations and flows of know-how do not serve to extend and reproduce exploitative class relations of domination, even be they under novel forms of sub/ Southern imperialism. This remains to be seen, and indeed the global crisis is affecting the terms of this debate.

\section{The Global Crisis and the Resilience of Neoliberalism}

The global crisis that emerged in the United States in 2007 was rooted in the preceding decades of neoliberal restructuring. Its immediate trigger, however, was the subprime mortgage lending debacle. The US subprime crisis then took a global turn in late September 2008 with the collapse of the US investment bank Lehman Brothers. As investors scrambled to preserve their wealth and dump any toxic assets they had bought into, otherwise liquid US credit markets seized up, bringing the global financial system to the edge of ruin. Only massive and sustained state intervention prevented the system's implosion. Many Western governments rolled out financial Keynesianism. This entailed nationalising failed private banks and industries and adding trillions of dollars to the public debt. The governments thus staved off global economic collapse but only by incurring massive increases in new public debts. This gave rise to the sovereign debt crises in the 'peripheral' EU countries. A number of developing countries also incurred new public debts as governments rolled out economic stimulus packages to help sustain domestic investment, maintain employment and buttress internal demand.

On the one hand, the privileges and powers gained by global capital under neoliberal transformation remain largely intact. Indeed, imperialist governments have done everything in their power to reinforce the current system. Such is the aim of the quantitative easing and zero interest rate policies being pursued by the US Federal Reserve, the Banks of England and Japan, and increasingly the European Central Bank. These actions are intended to prop up the financial markets, support the prices of financial assets and make these countries' exports more competitive. Throughout it all neoliberal technocrats remain unwavering in their ideological commitments to market-oriented development. For example, the World Bank's Global Financial Development Report 2013 attempts to reframe the global crisis not as a fundamental problem of 'market failure' and capitalism, but instead as essentially about 'state failure' and flawed human nature. The solution? More of the same neoliberal policies implemented since the 1980s, but now guided and sustained by a more robust state apparatus that ensures better market discipline. Despite such socially costly crisis and recovery processes, 
reproduced by specific permission under license

neoliberalism remains largely intact and unscathed among the globe's major international policymakers (Marois, 2012: 208-13).

On the other hand, the interests of those workers, peasants and women who did not cause the crisis have been targeted and undermined in efforts to overcome the crisis. By socialising the costs through the state apparatus, governments have forced workers and popular classes to pay for the crisis (Marois, 2014). In Western countries, austerity has reinforced preceding trends towards increased poverty and social inequality, disproportionately impacting workers, especially immigrant workers, and women. This is discursively framed around the need to renew growth. In this narrative, the banker, the bureaucrat and the baker's helper are all in it together. Nothing is further from the truth. The point is, as David McNally argues in his chapter on the United States, that in a context of sluggish profitability, austerity is necessary for capital to increase labour exploitation and profits. Likewise, Lucia Pradella investigates the global political economic roots and social impacts of the crisis in Western Europe. Other contributors focus attention on the Middle East, Africa, Latin America and Asia.

Workers and popular classes may be down, but they are not out. In response to the rank injustice meted out by those in power wishing to preserve capitalism in the wake of the crisis, social resistances have arisen anew. Contributors to this book highlight their spectacular range and diversity, starting from the development of a revolutionary movement in the Arab world, presented by Adam Hanieh. Yet this book's contributors are under no illusion that economic crisis alone will launch the collapse of neoliberalism or capitalism. So long as neoliberal advocates are able to push the costs of crisis systematically onto workers, women and oppressed peoples, capitalists will find means of reproducing this exploitative system. That said, the crisis and the movements emerging in response have reopened an opportunity to envision, and fight for, substantial alternatives.

\section{The Limits of New Developmental Alternatives}

The immediate aftermath of the global crisis raised the spectre of global Keynesianism. The long-standing institutionalist thesis necessitating the extramarket role of the state in sustaining capitalist growth and stability seemed vindicated. In the Global South too, new developmentalist strategies appeared justified. The rejuvenated developmental state was contributing to an apparent post-crisis global recovery, nowhere more visible than in China with its massive capital infusions.

There is an internal logic to their reassertion of the state. New developmental scholars understand neoliberalism primarily through an institutional lens as various manifestations of the Washington consensus policies. As new developmentalists see it, then, the real problem is that these market-oriented policies have failed to produce stable growth and reduce inequality. Rather, recurrent crises and instability have created boom/bust growth cycles and worsened 


\section{reproduced by specific permission under license}

inequality. It follows that neoliberalism is essentially a 'policy error' characterised by excessive regulatory slippage. By implication, a break with neoliberalism can be achieved by a 'return of the state' (Grugel and Riggirozzi, 2012). However, as this debate is only concerned with how to best achieve virtuous cycles of capitalist growth, capitalism itself is never in question. Merely the pace, timing and institutional strength of changes in the regulatory environment of 'national' capitalisms are questioned. New developmentalism, advocates argue, would allow a return to an 'original' development path devoid of the labour repression, climate change, gender inequality and state bureaucratisation characteristic of the first developmentalism (Kahn and Christiansen, 2011: 5; 255-7).

New developmentalists present one pole of the debate over alternatives. Contributors to this book present another, radically opposite pole. From our perspective, and for present purposes, we signal four main limitations to the new developmentalist approach to alternatives.

First, new developmentalists ignore the exploitative nature of capitalist production relations. For example, many stress that national progressive competitiveness strategies should drive up domestic productivity. In this thesis, poverty is reduced to a symptom of interrupted cycles of otherwise virtuous growth. Yet, as both Benjamin Selwyn and Dae-Oup Chang argue in this book, new developmentalist strategies obscure the systematic repression of workers' rights, wages and human aspirations through the state apparatus. Focusing more on growth and mitigating economic inequality, most developmentalists set aside capitalism's inherent tendency towards social polarisation. Consequently, constitutive issues of social reproduction and of the deepening ecological crisis remain largely on the sidelines.

Second, new developmentalists uphold an idealised understanding of the state. In this paradigm, states are understood as autonomous and elite institutions that can moderate capitalist development for the overall 'social good'. The underlying historical social relations of class, gender and race constitutive of the state apparatus are typically papered over in this framework, and how change is achieved and consolidated, and who benefits from it, are thus distorted.

Third, new developmentalism also rests on methodologically nationalist assumptions, and reproduces the same state/market and national/international dualisms characteristic of neoclassical economics (see Pradella, 2014). Primacy is given to the 'extra-market' coordinating role of the state in instituting national comparative advantages in the world market. If achieved, then free trade can once again positively benefit all participating countries. Concretely, scholars point to the national developmental successes of East Asia, and more recently China, as dehistoricised, decontextualised and discrete developmental models seemingly transferable to all developing countries.

Fourth, it follows that new developmentalists underestimate imperialist relations and capitalism's tendency towards uneven and combined development. As Alfredo Saad-Filho illustrates in this book, mainstream expectations of global economic convergence are exaggerated since the underlying driving forces of 
reproduced by specific permission under license

neoliberal globalisation, which lead towards persistent economic polarisation, are still operating. Development in the South continues to be very uneven and characterised by complex hierarchical patterns of international integration and deindustrialisation. Looking to Africa, Baba Aye's contribution points to the 'new scramble for Africa' as emerging capitalisms like China are solidifying their place in Africa as new trade and financial partners, thus intensifying international competitive imperatives on the continent. Similar patterns of uneven and combined development in the Middle East, East Asia and Latin America are documented elsewhere in the book. Jerome Klassen, moreover, discusses how the weakening of US and Western hegemony is intensifying international rivalries and military tensions.

In the final assessment, new developmentalism admirably targets some of neoliberalism's economic failures, seeks to craft virtuous cycles of stable growth and to alleviate poverty. The structural power of capital and the systematic exploitation of workers are nonetheless repackaged and reproduced. New developmentalism only modifies neoliberalism as a form of class rule responding to labour and social mobilisations. At the same time the post-crisis consolidations of what have been defined as new developmentalist governments have given rise to new social tensions. As Tim Pringle argues in the book, there is a mounting sense of collective consciousness and power arising within the Chinese working class. And China is by no means the only case. Over the last several years significant protest waves and movements have erupted in Russia, India, South Africa, Brazil, Mexico, Thailand and Turkey. The crisis is indeed global. Despite much rhetoric, the BRICS countries have not formed a real alliance and they remain dependent on exports to and financial relations with imperialist countries, with their economic growth now decelerating or stopping altogether. There is a great need, therefore, to elaborate on real alternatives to neoliberal capitalism.

\section{What Makes for Substantive Developmental Alternatives?}

Contributors to this book share an understanding that many societies are in dire need of substantive alternatives to both neoliberal capitalism and its new developmentalist variants. But what does this mean? While we do not ascribe to a single, shared vision (nor need we), each contributor has tried to identify and signal various progressive tendencies that arise from the specific contexts, cases and struggles they have dealt with - be it from women's struggles in Turkey, Cambodia or Venezuela, from revolutionary lessons in Latin America and the Middle East, or from the many labour resistances discussed. We accepted at the start of the project that alternatives cannot and do not simply arrive pre-formed from outside existing society. In other words, the struggle to break with neoliberal capitalism necessarily begins within the historical confines of neoliberalism. Consequently, alternatives must be sought in everyday and actually existing struggles. 


\section{reproduced by specific permission under license}

To recognise the necessarily historical specificity of struggles to overcome neoliberal capitalism is not to abandon universal aspirations for social justice or common strategies of resistance. On the contrary, by analysing how capitalism works, contributors to this book have tried to provide an analytical framework within which a strategy of change can be shaped. To this end, we share a baseline understanding of what is needed to constitute an alternative. That is, any alternative must stand in sharp contrast to any form of exploitation and oppression, and it must be achieved through working and popular class agency. There is no evidence that capitalists and their advocates will relinquish their accumulated institutional and material power and control willingly. Progressive change must be achieved from below.

Given this shared baseline, it is worth highlighting some of the concrete strategies and principles that emerge throughout the book.

- Worker-led resistances and aspirations: Various contributors point to how the gains made by workers and popular classes are due to their collective mobilisations. Many argue that the sustainability of struggles for progressive alternatives depends on the capacity of labour and social movements to build local, national, regional and international movements oriented toward structural transformation. Abelardo Mariña-Flores and Jeffery Webber discuss this perspective with regard to Latin America. Rohini Hensman, Dae-oup Chang and Tim Pringle highlight the potential of the massive working classes in Asia and their capacity to disrupt capitalist production globally. Other contributors highlight the importance of establishing cooperative productive and economic capacity as a prerequisite for more solidarity-based and worker-led social economies. Leandro Vergara-Camus, in particular, discusses the successes of the regional Zapatista movement in Mexico and national Landless Movement in Brazil, but questions the extent to which these forms of peasant resistance are generalisable. Other contributors identify the length of the working day as a key terrain of social transformation, and affirm the centrality of creating autonomous working class political organisations with an internationalist and anti-imperialist perspective. If the global restructuring of production and international migration potentially strengthens the working class internationally, various contributors reflect on the strategies needed to unify workers across the North/South divide and beyond national and racialised divisions (see John Smith, Pietro Basso, Laura Horn and Angela Wigger). For Klassen, an effective anti-war movement has to be based on a new solidarity of working class and oppressed peoples' struggles.

- Equitable social reproduction: Various contributors highlight the crucial importance of women's agency in challenging the gendered inequalities of neoliberal production and social reproduction. Drawing on socialist feminist tenets, Demet Özmen Yilmaz (in the case of Turkey) and Susan Spronk and Sarah Miraglia (in the cases of Venezuela and Cambodia) explore women's agency in these societies. Their contributions point to the need to fight for 
reproduced by specific permission under license

renewed public services to alleviate the unequal burdens women face day in and day out. Contributors also highlight the need to radically question allegedly natural gender roles in the domestic sphere. At the same time, the differential exploitation of women workers needs to be addressed, defending women's rights as women and as workers. Various contributors highlight the enormous potential for these struggles, including the crucial role of women in the Arab uprisings and in the struggles sparked by the Rana Plaza disaster in Bangladesh (see Hanieh and Smith in this book).

- Renewing and democratising the public sector: There is no escaping the struggle to substantively democratise the public sector. To the extent that new developmentalists seek alternatives to neoliberalism, state-owned and public services are presented as alternatives simply because they are not privately owned. Contributors to this book share no such illusions: public services can be aggressively neoliberal in their operations. To recognise this is not to reject the public sector as a necessary, if not sufficient, condition for breaking with neoliberalism. Public ownership can provide a powerful stimulus towards more collective social ownership and the democratisation of political and economic processes. Yet this is no straightforward process. David McDonald's chapter points to many struggles aiming to protect public service provisioning globally. In doing so he proposes a clearer definition of 'publicness' and an alternative methodology by which we can critically evaluate and improve public services for the social good. Likewise, Thomas Marois points to the massive capacity that still-existing state banks hold globally. He argues that capturing and democratising these public sources of credit, along with the dispossession of the accumulated wealth and power of financial capital, are necessary features of any sustainable alternative to neoliberalism. The knock-on benefits of exerting democratic control over society's monetary resources are substantial: solidaristic funding for public services, public infrastructure and cooperatives, as well as for gendered and green social developmental initiatives.

- Social and environmental justice: Many contributors to this book accept that environmental struggles are intimately tied to workers' and women's aspirations. Andreas Malm's contribution investigates the links between struggles against climate change and for social justice. He highlights the strategic role of industrial workers for realising this transformation, potentially unifying the entire working class and its social allies, including women's and peasant-based struggles against dispossession and environmental destruction. Hugo Radice's contribution further argues that an alternative, socialist society must be characterised by the material equality of all its members as the basis for free and equal participation in processes of production and reproduction, respectful of the environment.

By criticising neoliberalism and by reflecting on the forms alternatives have taken and are taking, this book tries to 'polarise development'. This direction is meant not just to criticise existing social polarisations, but also to recognise the seeds 


\section{reproduced by specific permission under license}

of material interdependence and class power existing within the present society. In different ways, workers, women and social movements all over the world are trying to oppose the exploitative and oppressive social relations of capitalist rule. As the crisis continues to unfold and deepen, it is increasingly imperative that any realistic alternatives to neoliberalism move beyond the pole of 'reform and reproduce' and toward a radical break with capitalism itself. None of the strategies and principles presented in this book, on their own, are assumed to be sufficient to realise such a break. Nevertheless, in important and transformative ways, they each may contribute to advancing in this direction. We do not wish for this book to remain at the level of debate. Rather, we see it as a contribution to the struggles of workers and social movements, who are the real forces that can polarise development and subordinate it to real social needs.

\section{Select bibliography}

Arrighi, G. (2007) Adam Smith in Beijing: Lineages of the Twenty-First Century. London: Verso.

Burbach, R., Fox, M. and Fuentes, F. (2013) Latin America's Turbulent Transitions: The Future of Twenty-First-Century Socialism. Winnipeg and New York: Fernwood and Zed Books.

Grugel, J. and Riggirozzi, P. (2012) 'Post-neoliberalism in Latin America: rebuilding and reclaiming the state after crisis', Development and Change, 43(1): 1-21.

Kahn, S. R. and Christiansen, J. (eds) (2011) Towards New Developmentalism: Market as Means Rather Than Master. Abingdon and New York: Routledge.

Marois, T. (2012) States, Banks, and Crisis: Emerging Finance Capitalism in Mexico and Turkey. Cheltenham, Glos.: Edward Elgar.

Marois, T. (2014) 'Historical precedents, contemporary manifestations: crisis and the socialization of financial risk in neoliberal Mexico', Review of Radical Political Economics, 46(3).

Patomäki, H. (2012) The Great Eurozone Disaster: From Crisis to Global New Deal. London: Zed Books.

Pradella, L. (2014) 'New developmentalism and the origins of methodological nationalism', Competition and Change, 18(2): 180-93.

Prashad, V. (2013) The Poorer Nations: A Possible History of the Global South. London: Verso.

Shaikh, A. (2005) 'The economic mythology of neoliberalism', pp. 41-49 in A. Saad-Filho and D. Johnston (eds), Neoliberalism: A Critical Reader. London: Pluto. 